\title{
Supercapacitive Properties of Activated Carbon-Quinone Derivative Composite Electrode in Different Hydrogen ion Conducting Electrolytes
}

\author{
Mohammed Latifatu', Hae Soo Lee, Choog Sup Yoon ${ }^{2}$, Jemyung Oh ${ }^{3}$, Jeong Ho Park ${ }^{1, *}$, \\ Jang Woo Park, Jang Myoun Ko ${ }^{1, *}$ \\ ${ }^{1}$ Department of Chemical and Biological Engineering, Hanbat National University, Daejon 305-719, \\ South Korea \\ ${ }^{2}$ Advanced Materials, Hanbat National University, Daejon 34158, Repubic of Korea \\ ${ }^{3}$ Materials Engineering Department, Adama Science and Technology University, Ethiopia \\ *E-mail: jmko@hanbat.ac.kr, jhpark@hanbat.ac.kr
}

doi: $10.20964 / 2016.07 .33$

Received: 24 February 2016 / Accepted: 18 March 2016 / Published: 4 June 2016

A composite electrode (CE) consisting of activated carbon and quinine derivative 2-((2-(1H-indol-3yl) ethyl) amino) naphthalene-1, 4-dione (HBU-551) was probed in different hydrogen ion conducting electrolytes such as sulfuric acid $\left(\mathrm{H}_{2} \mathrm{SO}_{4}\right)$, hydrochloric acid $(\mathrm{HCl})$, Phosphoric acid $\left(\mathrm{H}_{3} \mathrm{PO}_{4}\right)$ and ammonium chloride $\left(\mathrm{NH}_{4} \mathrm{Cl}\right)$. The electrochemical performances of the $\mathrm{CE}$ in the electrolytes were investigated by cyclic voltammetry (CV), electrochemical impedance spectroscopy (EIS) and chargedischarge. The different hydrogen ion conducting electrolytes with different ionic conductivity induce different electrochemical properties in the $\mathrm{CE}$. The specific capacitance is in the order of $\mathrm{H}_{2} \mathrm{SO}_{4}>$ $\mathrm{H}_{3} \mathrm{PO}_{4}>\mathrm{HCL}>\mathrm{NH}_{4} \mathrm{Cl}$ at $100 \mathrm{mV} / \mathrm{s}$ and a potential range of $-0.2-0.8$ ( V vs $\left.\mathrm{Ag} / \mathrm{AgCl}\right)$.

Keywords: Quinone derivative, composite electrode, proton conducting electrolyte, supercapacitor

\section{$\underline{\text { FULL TEXT }}$}

(C) 2016 The Authors. Published by ESG (www.electrochemsci.org). This article is an open access article distributed under the terms and conditions of the Creative Commons Attribution license (http://creativecommons.org/licenses/by/4.0/). 